\title{
MORTALITAS, PENGHAMBATAN MAKAN DAN PERTUMBUHAN HAMA DAUN GAHARU HEORTIA VITESSOIDES MOORE OLEH EKSTRAK BUAH BRUCEA JAVANICA (L.) MERR.
}

\author{
Agus M. Hariri \\ Bidang Proteksi Tanaman Jurusan Agroteknologi, Fakultas Pertanian, Universitas Lampung \\ Jl. Sumantri Brodjonegoro No. 1 Bandar Lampung 35145 \\ E-mail: agusmhariri@yahoo.com
}

\begin{abstract}
Mortality, antifeedance and growth inhibition of agarwood defoliator Heortia vitessoides Moore due to the fruit extract of Brucea javanica $(\boldsymbol{L}$.) Merr. The bioassay of Brucea javanica fruit extract was performed to evaluate lethal and antifeedance effect as well as growth inhibition against agarwood defoliator Heortia vitessoides. Three types of Brucea (unripe, ripe, and dried fruits) were extracted with maceration method in aquadest for 24 hours. Tests were done using leaf-residual method. The results showed that mortality of $H$. vitessoides larvae was significantly higher when applied with Brucea extract at concentration $50 \mathrm{~g} / \mathrm{l}$ compared to control starting at two days after application. Moreover the dried fruit extract killed all insect test in three days after application. The other result indicated that pupation of agarwood defoliator was less than $10 \%$ and emerging adult was $0 \%$ when applied with Brucea fruit extracts. In addition, at two days after application of ripe and dried fruit extracts resulted antifeedance effect against $H$. vitessoides larvae 68-70\% leaves weight and 74-77\% based on eaten leaf area.
\end{abstract}

Key words: lethal effect, antifeedance, Brucea javanica, Heortia vitessoides

\begin{abstract}
ABSTRAK
Mortalitas, penghambatan makan dan pertumbuhan hama daun gaharu Heortia vitessoides Moore oleh ekstrak buah Brucea javanica (L.) Merr. Uji hayati terhadap ekstrak buah Brucea javanica telah dilakukan untuk mengetahui pengaruh letal, penghambatan makan serta pertumbuhan hama pemakan daun gaharu Heortia vitessoides. Tiga jenis buah Brucea (buah muda, buah tua, dan buah kering) diekstrak dalam akuades dengan metode maserasi selama 24 jam. Pengujian dilakukan dengan metode residu pada daun. Hasil penelitian menunjukkan bahwa ekstrak buah Brucea muda, tua, maupun kering pada konsentrasi $50 \mathrm{~g} / \mathrm{l}$ nyata efektif menyebabkan mortalitas larva $H$. vitessoides sebesar 73,3-95,5\% sejak dua hari setelah diaplikasikan. Bahkan ekstrak buah kering telah mematikan seluruh serangga uji pada hari ke-3 setelah aplikasi. Akibat perlakuan ekstrak buah Brucea hanya kurang dari 10\% larva uji yang dapat menjadi pupa dan tidak satu pun yang mencapai tahap imago. Selain hal itu juga diketahui bahwa pada 2 hari setelah aplikasi, ekstrak buah tua dan buah kering memiliki pengaruh antifeedant terhadap larva $H$. vitessoides sebesar $68-70 \%$ berdasarkan bobot daun dan $74-77 \%$ berdasarkan luas daun yang dimakan serangga tersebut.
\end{abstract}

Kata kunci: efek letal, penghambatan makan, Brucea javanica, Heortia vitessoides

\section{PENDAHULUAN}

Brucea javanica (L.) Merr. adalah tumbuhan famili Simaroubaceae yang dideskripsi oleh Merril pada 1928 (Paczkowska, 1996). Tumbuhan tersebut antara lain dikenal dengan nama umum 'buah makasar' (macassar kernels) (Roberts, 1994), walaupun di daerah Sulawesi Selatan sendiri disebut dengan tambara marica (Globinmed, 2010). Di sejumlah daerah lainnya tumbuhan ini disebut dengan nama yang berbeda, seperti melur (Sumatera Utara), kwalot (Jawa), lada pahit atau mempahit (Malaysia) (Globinmed, 2010). Tumbuhan perdu dengan batang berkayu itu tumbuh setinggi 2-3 meter, berdaun majemuk berbentuk lonjong meruncing dan sedikit bergerigi pada tepinya. Buahnya bulat sebesar 4-7 mm, berkulit tipis, berwarna hijau ketika muda dan ungu-kehitaman setelah tua, sedangkan bijinya bulat berwarna putih. Tumbuhan ini tersebar luas dari Sri Lanka, kawasan Asia Tenggara sampai Cina dan Taiwan, juga New Guinea, hingga Australia dan Kepulauan Fiji (Roberts, 1994).

B. javanica sejak lama telah dikenal sebagai tumbuhan yang memiliki berbagai khasiat obat (Jayaweera, 1982). Bagian-bagian tumbuhan tersebut - terutama buahnya - memiliki rasa pahit dan telah digunakan untuk mengobati sejumlah penyakit seperti disenteri, malaria, cacing gelang dan cacing pita serta trichomoniasis, amoebeasis, dan babesiosis (Roberts, 
1994; WHO, 1999; Nakao et al., 2009). Tumbuhan tersebut mengandung banyak zat bioaktif yang termasuk dalam dua golongan senyawa, yaitu alkaloid dan quassinoid. Canthin-6-one adalah salah satu senyawa yang tergolong alkaloid (Liu et al., 1990), sedangkan golongan quassinoid antara lain meliputi bruceolide, bruceine A, B, dan C. Kemudian juga ditemukan kandungan bruceine $\mathrm{D}, \mathrm{E}, \mathrm{F}$, dan $\mathrm{G}$, serta bruceantin, bruceantinol, bruceantarin, dehidrobruceantol, dan brusatol (Roberts, 1994). Bruceantin dan bruceantinol lebih lanjut diketahui sebagai senyawa yang memiliki daya kerja anti-leukemia (Roberts, 1994), sedangkan brusatol dikenal sebagai senyawa anti-tumor (Okano et al., 1995).

B. javanica juga diketahui memiliki daya kerja sebagai insektisida (Liu et al., 1990) dan penghambat aktivitas sejumlah virus tumbuhan (Shen et al., 2008). Menurut Zeng et al. (2006) pemberian ekstrak buah Brucea secara signifikan menghambat aktivitas makan serta pertumbuhan dan perkembangan ulat Pieris rapae. Sejumlah penelitian lainnya menunjukkan bahwa ekstrak buah tersebut dapat menghambat peneluruan wereng coklat hingga 70\% (Qin et al., 2007), serta memiliki toksisitas yang tinggi terhadap Myzus persicae (Shang et al., 2008), juga terhadap Crocidolomia pavonana (Syahputra, 2008) dan Plutella xylostella (Lina et al., 2010) serta Spodoptera exigua (Feng et al., 2012).

Upaya memperluas kemungkinan pemanfaatan Brucea untuk mengendalikan hama lainnya telah dilakukan dengan mengaplikasikannya terhadap ulat pemakan daun gaharu Heortia vitessoides Moore (Lepidoptera: Crambidae). Gaharu adalah salah satu komoditas hasil hutan non kayu yang memiliki nilai ekonomi tinggi serta peran yang penting dalam peningkatan pendapatan masyarakat dan devisa negara. Gaharu merupakan kayu resin yang dihasilkan oleh tumbuhan dari genus Aquilaria dan Gyrinops (Famili Thymelaeaceae) selama ini banyak digunakan sebagai bahan parfum, kosmetika, dan obat-obatan. Tumbuhan penghasil gaharu tersebut berupa semak hingga pohon yang diameternya bisa mencapai 0,6 meter dan tinggi hingga 6-21 meter. Di Indonesia terdapat tidak kurang dari 26 spesies pohon penghasil gaharu yang tersebar di Sumatera, Kalimantan, Sulawesi, Nusa Tenggara, Maluku, dan Papua (Irianto et al., 2010; Siran \& Turjaman, 2010).

Akibat perdagangan dan pemanenan gaharu yang intensif dari hutan alami menyebabkan banyak spesies pohon gaharu kian langka. Upaya konservasi di luar habitat aslinya (ex-situ) berupa budidaya tanaman gaharu secara luas dan monokultur telah menimbulkan serangan hama ulat daun Heortia vitessoides di sejumlah daerah seperti Carita (Banten), Sanggau (Kalimantan Barat), dan Mataram (Nusa Tenggara Barat) (Irianto et al., 2010; Santoso et al., 2011). Bahkan negara penghasil gaharu dunia, seperti India, sudah mengalami problem ulat tersebut sejak 1998 (Gurung et al., 2002; Kalita et al., 2002). Ulat berwarna kuning muda, berukuran 3,5 mm saat baru menetas itu pada instar-3 dan 4 berukuran 20,9 mm, berwarna hijau kekuningan dengan bintik-bintik hitam yang massif hingga tampak berciri garis hitam yang membujur pada kedua sisi tubuhnya. Adapun kepala ulat tersebut berwarna coklat (Gurung et al., 2002; Kalita et al., 2002; Evans \& Crossley, 2010).

Selain pada tanaman gaharu, $H$. vitessoides juga berinang pada 'mahkota dewa' (Phaleria macrocarpha) yang dikenal sebagai salah satu jenis tanaman obat, yang keduanya adalah sefamili (Thymelaeaceae) (Irianto et al., 2010; Santoso et al., 2011). Di Lampung sejak 2008 H. vitessoides telah menyerang banyak tanaman mahkota dewa. Serangannya bisa menimbulkan kerusakan tanaman 70 - $100 \%$. Pada saat puncak populasi, pohon mahkota dewa tampak dipenuhi oleh ulat yang dengan rakus memakan hampir seluruh daun bahkan hingga ke buahnya. Beberapa tanaman mengalami defoliasi total dan selanjutnya mengalami kematian (Hariri \& Indriyati, 2011).

Strategi pengendalian hama $H$. vitessoides pada jangka pendek menurut Irianto et al., (2010) antara lain dengan pengendalian secara mekanik, penggunaan insektisida kimia, dan insektisida nabati. Guna memberi kontribusi terhadap upaya pengendalian hama tersebut, penelitian ini bertujuan untuk mengetahui peluang penggunaan secara sederhana ekstrak buah Brucea javanica sebagai insektisida nabati untuk mengendalikan hama $H$. vitessoides melalui pengaruh penghambatan makan dan perkembangan serta mortalitas yang ditimbulkannya pada serangga tersebut.

\section{METODE PENELITIAN}

Tempat dan Waktu. Penelitian dilaksanakan di Laboratorium Hama Tumbuhan Fakultas Pertanian Universitas Lampung sejak November 2010 hingga Juni 2011.

Penyiapan Serangga Uji. Kelompok telur Heortia vitessoides, atau larva instar-1, diambil dari tanaman mahkota dewa (Phaleria macrocarpa) terserang, yang ada di arboretum kampus Universitas Lampung. Selanjutnya kelompok telur dan larva tersebut dipelihara 
di laboratorium di dalam bejana plastik bertutup kain kasa dan diberi pakan daun mahkota dewa segar hingga menjadi imago. Selanjutnya serangga-serangga dewasa tersebut dipelihara di dalam kurungan $(40 \times 40 \times 60 \mathrm{~cm})$ yang berdinding kain kasa dan diberi pakan larutan madu 25\% sampai bertelur. Kelompok-kelompok telur ditempatkan pada sejumlah bejana plastik bertutup kain kasa hingga menetas. Kemudian larva dipilah berdasarkan waktu penetasan yang seragam, diberi pakan daun mahkota dewa segar, dan dijadikan serangga uji ketika memasuki instar-3.

Penyiapan Ekstrak Buah Brucea. Pada penelitian ini digunakan tiga macam buah Brucea sebagai perlakuan, yaitu buah muda yang berwarna hijau, buah tua yang berwarna hitam, dan buah kering yaitu buah tua yang dijemur di bawah panas matahari selama 7 hari.

Ekstrak buah Brucea yang diujikan adalah hasil ekstraksi sederhana dengan maserasi (perendaman) dalam akuades, dengan tujuan untuk pendekatan penggunaan praktis petani di lapangan. Proses ekstraksi diawali dengan penghalusan buah Brucea menggunakan blender selama 30 menit hingga menjadi pasta (buah muda) dan serbuk (buah tua dan buah kering). Serbuk buah tua dan buah kering diayak dengan pengayak kasa bermata $1 \mathrm{~mm}$. Selanjutnya sebanyak 50 gram bahan tersebut dicampur dengan 1 liter akuades direndam selama 24 jam, masing-masing pada labu gelas yang terpisah. Setelah disaring dengan kertas saring ekstrak buah Brucea siap digunakan untuk pengujian.

Konsentrasi ekstrak yang diujikan adalah 50 g/l, sesuai dengan Prijono (2005) yang menyatakan jika ekstraksi dilakukan dengan pelarut organik konsentrasi yang digunakan pada pengujian awal hendaknya tidak lebih dari $0,5 \%$, sedangkan jika ekstraksi dilakukan dengan air konsentarsi pengujian hendaknya tidak melebihi $50 \mathrm{~g} / \mathrm{l}$ untuk bahan tumbuhan berupa biji dan tidak melebihi $100 \mathrm{~g} / \mathrm{l}$ untuk bahan selain biji.

\section{Pengujian Ekstrak Buah Brucea terhadap Mortalitas dan Pertumbuhan $\boldsymbol{H}$. vitessoides.} Pengujian pengaruh ekstrak buah Brucea terhadap mortalitas larva instar-3 H. vitessoides dilakukan dengan metode residu pakan yang disusun dalam rancangan acak lengkap dengan 3 ulangan dan 4 perlakuan (ekstrak buah muda, ekstrak buah tua, ekstrak buah kering, dan kontrol). Daun mahkota dewa segar dipotong-potong hingga berukuran seragam $4 \times 4 \mathrm{~cm}$ kemudian dicelupkan ke dalam sediaan masing-masing perlakuan ekstrak buah Brucea selama 10 detik. Sedangkan untuk kontrol potongan-potongan daun mahkota dewa dicelup ke dalam akuades. Kemudian daun-daun tersebut diangkat dan dikeringanginkan selama 10 menit.

Selanjutnya sesuai dengan masing-masing perlakuan, daun-daun tersebut dimasukkan ke dalam bejana-bejana plastik (diameter $15 \mathrm{~cm}$, tinggi $8 \mathrm{~cm}$ ) sebanyak 10 lembar per bejana. Setelah itu 10 ekor larva $H$. vitessoides instar-3 dimasukkan ke dalam bejana tersebut. Setelah 24 jam larva $H$. Vitessoide dipindahkan ke dalam bejana lain dan diberi pakan baru yang juga mendapat perlakuan.

Pengamatan mortalitas larva dilakukan terhadap jumlah larva yang mati pada 12 jam setelah aplikasi, dan kemudian dilanjutkan setiap hari sampai dengan kematian larva mencapai $100 \%$ terjadi pada sejumlah perlakuan. Adapun data pertumbuhan dan perkembangan $H$. vitessoides terdiri atas jumlah larva instar-3 yang berhasil menjadi instar-4, jumlah pupa yang muncul, jumlah imago yang muncul, rerata umur (stadium) larva instar-3, rerata umur (stadium) larva instar-4, rerata umur (stadium) pupa, dan rerata umur (stadium) imago. Rerata umur (stadium) serangga uji dihitung dengan rumus sebagai berikut (Sokal \& Rohlf, 1981):

$$
\begin{aligned}
\bar{Y} w & =\frac{\sum_{i=1}^{n} w_{i} \cdot Y_{i}}{\sum_{i=1}^{n} W_{i}} \\
\sum_{i=1}^{n} W_{i} & =w_{1}+w_{2}+w_{3}+\ldots \ldots w_{n}
\end{aligned}
$$

dengan:

$\bar{Y} w=$ rerata tertimbang umur stadium $H$. vitessoides $w_{i}=$ jumlah $H$. vitessoides yang hidup pada hari ke- $i$ $Y_{i}=$ umur $H$. vitessoides sampai hari ke- $i$

$\sum_{i=1}^{n} W_{i}=\begin{aligned} & \text { jumlah total } H . \text { vitessoides yang hidup dari } \\ & \text { hari ke- } i \text { sampai hari ke- } n\end{aligned}$

Pengujian Penghambatan Makan $\boldsymbol{H}$. vitessoides oleh Ekstrak Buah Brucea. Pengujian dilakukan dengan metode residu pada daun pakan tanpa pilihan dan dengan pilihan. Satuan percobaan pada pengujian pakan daun tanpa pilihan disusun dalam Rancangan Acak Lengkap (RAL) terdiri atas 4 perlakuan ekstrak buah Brucea (buah muda, buah tua, buah kering, serta kontrol) dengan 10 ulangan. Setelah dilakukan analisis ragam, pembandingan nilai tengah perlakuan dilakukan dengan uji Beda Nyata Terkecil (BNT) pada taraf nyata 5\% atau $1 \%$. Adapun pada pengujian pakan daun dengan pilihan, untuk mengetahui penghambatan makan jenis 
ekstrak buah Brucea terhadap larva $H$. vitessoides, luas daun pakan yang dikonsumsi larva pada perlakuan dibandingkan dengan kontrol menggunakan uji-t berpasangan (Walpole, 1995).

Pengujian dilakukan dalam bejana plastik (diameter $15 \mathrm{~cm}$, tinggi $8 \mathrm{~cm}$ ) yang diberi alas kertas tisu dan penutup kain kasa. Pada pengujian pakan daun tanpa pilihan, daun yang telah diberi perlakuan dan kontrol diletakkan dalam bejana yang terpisah. Dalam setiap bejana, empat potongan daun perlakuan atau kontrol diletakkan pada seputar dasar bejana, kemudian empat ekor larva instar-3 yang baru ganti kulit dilepaskan ke dalamnya. Sedangkan pada pengujian dengan pilihan, sebanyak empat lembar potongan daun (2 daun perlakuan dan 2 daun kontrol) ditempatkan secara berseling pada sekeliling dasar bejana. Empat ekor larva instar-3 dilepas ke masing-masing bejana tersebut agar makan selama 24 jam. Daun yang tersisa dipetakan di atas kertas milimeter untuk menghitung luas daun yang dimakan. Aktivitas makan serangga uji juga diukur berdasarkan ukuran bobot daun. Potongan daun uji yang telah diukur luasnya ditimbang. Untuk menduga bobot kering awal, 40 potong daun (ukuran $4 \times 4 \mathrm{~cm}$ ) ditimbang dalam 10 ulangan penimbangan (empat potong daun per ulangan, kemudian dikeringkan dalam oven pada suhu $105^{\circ} \mathrm{C}$ selama 2 jam (Prijono, 2005). Daun yang telah dikeringkan ditimbang kembali dan proporsi bobot kering daun dihitung dengan rumus:

$$
\text { Proporsi bobot kering }=\frac{\text { Bobot kering }}{\text { Bobot basah }}
$$

Berdasarkan proporsi bobot kering, bobot kering awal daun yang digunakan untuk percobaan dapat dihitung. Selisih bobot kering awal dan bobot kering sisa merupakan bobot daun yang dimakan (Prijono, 2005). Percobaan diulang 10 kali untuk setiap jenis ekstrak. Pengukuran penghambatan makan serangga uji oleh ekstrak buah Brucea, pada pengujian pakan daun tanpa pilihan, berdasarkan luas daun yang dimakan, dilakukan dengan rumus (Hassanali \& Bentley, 1987):

$$
\mathrm{PM}=1-\frac{\mathrm{Lp}}{\mathrm{Lk}} \times 100 \%
$$

dengan:

$\mathrm{PM}=$ penghambatan makan (\%),

$\mathrm{Lp}=$ rerata luas daun perlakuan yang dimakan,

$\mathrm{Lk}=$ rerata luas daun kontrol yang dimakan.

Penghambatan aktivitas makan juga dihitung berdasarkan bobot daun sebagai berikut (Prijono, 2005):

$$
\mathrm{PM}=\frac{(\mathrm{Bk}-\mathrm{Bp})}{(\mathrm{Bk})} \times 100 \%
$$

dengan:

$\mathrm{PM}=$ Penghambatan makan (\%),

$\mathrm{Bk}=$ bobot daun kontrol yang dimakan,

$\mathrm{Bp}=$ bobot daun perlakuan yang dimakan.

Adapun pada pengujian pakan daun dengan pilihan, penghambatan makan serangga uji, berdasarkan luas daun yang dimakan, dihitung dengan rumus berikut (Prijono, 2005):

$$
\mathrm{PM}=\frac{(\mathrm{Lk}-\mathrm{Lp})}{(\mathrm{Lk}+\mathrm{Lp})} \times 100 \%
$$

dengan:

$\mathrm{PM}=$ penghambatan makan (\%),

$\mathrm{Lk}=$ luas daun kontrol yang dimakan,

$\mathrm{Lp}=$ luas daun perlakuan yang dimakan.

Sedangkan penghambatan makan, berdasarkan bobot daun yang dimakan, dihitung dengan rumus berikut (Prijono, 2005):

$$
\mathrm{PM}=\frac{(\mathrm{Bk}-\mathrm{Bp})}{(\mathrm{Bk}+\mathrm{Bp})} \times 100 \%
$$

dengan:

$\mathrm{PM}=$ penghambatan makan $(\%)$,

$\mathrm{Bk}=$ bobot daun kontrol yang dimakan,

$\mathrm{Bp}=$ bobot daun perlakuan yang dimakan .

\section{HASIL DAN PEMBAHASAN}

Mortalitas Larva $H$. vitessoides Akibat Aplikasi Ekstrak Buah B. javanica. Hasil penelitian menunjukkan bahwa ekstrak air buah Brucea javanica pada konsentrasi $50 \mathrm{~g} /$ liter memiliki pengaruh letal yang kuat terhadap ulat pemakan daun gaharu Heortia vitessoides. Dalam waktu 12 jam sejak diaplikasikan, ekstrak buah Brucea belum memberikan pengaruh yang nyata terhadap terjadinya mortalitas larva $H$. vitessoides. Pengaruh letal dari ketiga jenis ekstrak tersebut (buah muda, buah tua, dan buah kering) tampak nyata mulai 1 hari setelah aplikasi, dan semakin meningkat pada beberapa hari berikutnya. Pada hari kedua mortalitas serangga uji akibat ekstrak buah Brucea mencapai 73,33 - 95,55\%. Bahkan ekstrak buah kering telah menyebabkan kematian seluruh serangga uji pada hari ketiga setelah aplikasi. Adapun pengaruh letal dari ekstrak buah Brucea muda dan tua terlihat telah menyebabkan mortalitas lebih dari $90 \%$ ulat $H$. vitessoides sejak hari kelima setelah diaplikasikan (Tabel 1). Kuatnya daya racun ekstrak buah Brucea terhadap serangga juga didapatkan oleh Syahputra (2008) yang menguji ekstrak metanol buah tersebut pada kisaran kosentrasi 0,06-0,25\% menimbulkan mortalitas larva Crocidolomia pavonana $8,3-86,7 \%$. Penelitian 
Shang et al. (2008) juga menunjukkan bahwa ekstrak metanol biji Brucea terlihat memiliki daya racun secara kontak terhadap kutudaun Myzus persicae yang menimbulkan kematian 98,8\% serangga tersebut pada hari ke-2 setelah diaplikasikan, sedangkan ekstrak daunnya menunjukkan indikasi sebagai racun perut yang dalam waktu 2 hari menimbulkan mortalitas $87,8 \%$ kutudaun tersebut. Lina et al. (2010) yang menguji tiga bentuk sediaan Brucea terhadap larva $C$. pavonana : ekstrak kasar, serta ekstrak metanol dalam formulasi $\mathrm{EC}$, dan formulasi WP mendapatkan nilai LC50 berturutturut sebesar $0,25 \%, 0,39 \%$, dan $0,21 \%$, sedangkan formulasi EC terhadap P. xylostella nilai LC50 sebesar $0,31 \%$. Tingginya tingkat mortalitas serangga uji akibat perlakuan ekstrak Brucea pada konsentrasi $50 \mathrm{~g} / \mathrm{l}$ (jika diekstraks dengan air) maupun pada konsentrasi tidak lebih dari 0,5\% (jika diekstrak dengan pelarut organik) mengindikasikan layaknya pengkajian lebih lanjut bahan tumbuhan yang diduga berpotensi dalam pengendalian hama (Prijono, 2005).

Peningkatan mortalitas larva $H$. vitessoides akibat perlakuan ketiga jenis ekstrak buah Brucea memang menunjukkan pola yang konsisten sejak hari ke-1 hingga ke-6, yaitu tertinggi pada ekstrak buah kering yang disusul berturut-turut oleh ekstrak buah tua dan buah muda. Demikian pula halnya dengan kecepatan dalam menimbulkan kematian terhadap seluruh serangga uji (Tabel 1; Gambar 1). Tetapi sesungguhnya secara esensi tidak berbeda di antara ketiga jenis ekstrak tersebut, karena mortalitas akibat perlakuan ekstrak

Tabel 1. Pengaruh ekstrak buah Brucea javanica terhadap mortalitas larva H. vitessoides

\begin{tabular}{lrcccccc}
\hline \multirow{2}{*}{ Perlakuan } & \multicolumn{7}{c}{ Mortalitas larva H. vitessoides pada - } \\
\cline { 2 - 8 } & 12 jsa & 1 hsa & 2 hsa & $3 \mathrm{hsa}$ & $4 \mathrm{hsa}$ & $5 \mathrm{hsa}$ & $6 \mathrm{hsa}$ \\
\hline Kontrol & 4,44 & $17,78 \mathrm{a}$ & $37,78 \mathrm{a}$ & $46,67 \mathrm{a}$ & $46,67 \mathrm{a}$ & $55,55 \mathrm{a}$ & $62,22 \mathrm{a}$ \\
Buah muda & 22,22 & $37,78 \mathrm{ab}$ & $73,33 \mathrm{~b}$ & $84,44 \mathrm{~b}$ & $88,89 \mathrm{~b}$ & $91,11 \mathrm{~b}$ & $91,11 \mathrm{~b}$ \\
Buah tua & 11,11 & $48,89 \mathrm{~b}$ & $86,67 \mathrm{bc}$ & $93,33 \mathrm{~b}$ & $95,55 \mathrm{bc}$ & $95,55 \mathrm{bc}$ & $97,78 \mathrm{bc}$ \\
Buah kering & 8,89 & $53,33 \mathrm{~b}$ & $95,55 \mathrm{c}$ & $100,00 \mathrm{c}$ & $100,00 \mathrm{c}$ & $100,00 \mathrm{c}$ & $100,00 \mathrm{c}$ \\
\hline F hitung $^{1)}$ & $2,43^{\text {tn }}$ & $4,24^{*}$ & $22,72^{* *}$ & $24,21^{* *}$ & $54,83^{* *}$ & $55,78^{* *}$ & $41,11^{* *}$ \\
\hline
\end{tabular}

jsa $=$ jam setelah aplikasi, hsa $=$ hari setelah aplikasi, ${ }^{1)}=$ data ditransformasi dengan $\sqrt{(x+0,5)}$, tn $=$ tidak berbeda nyata, $*$ = berbeda nyata pada taraf $5 \%, * *=$ berbeda nyata pada taraf $1 \%$, nilai-nilai dalam kolom yang diikuti huruf yang sama menunjukkan tidak berbeda menurut uji BNT ( $p>0,05)$

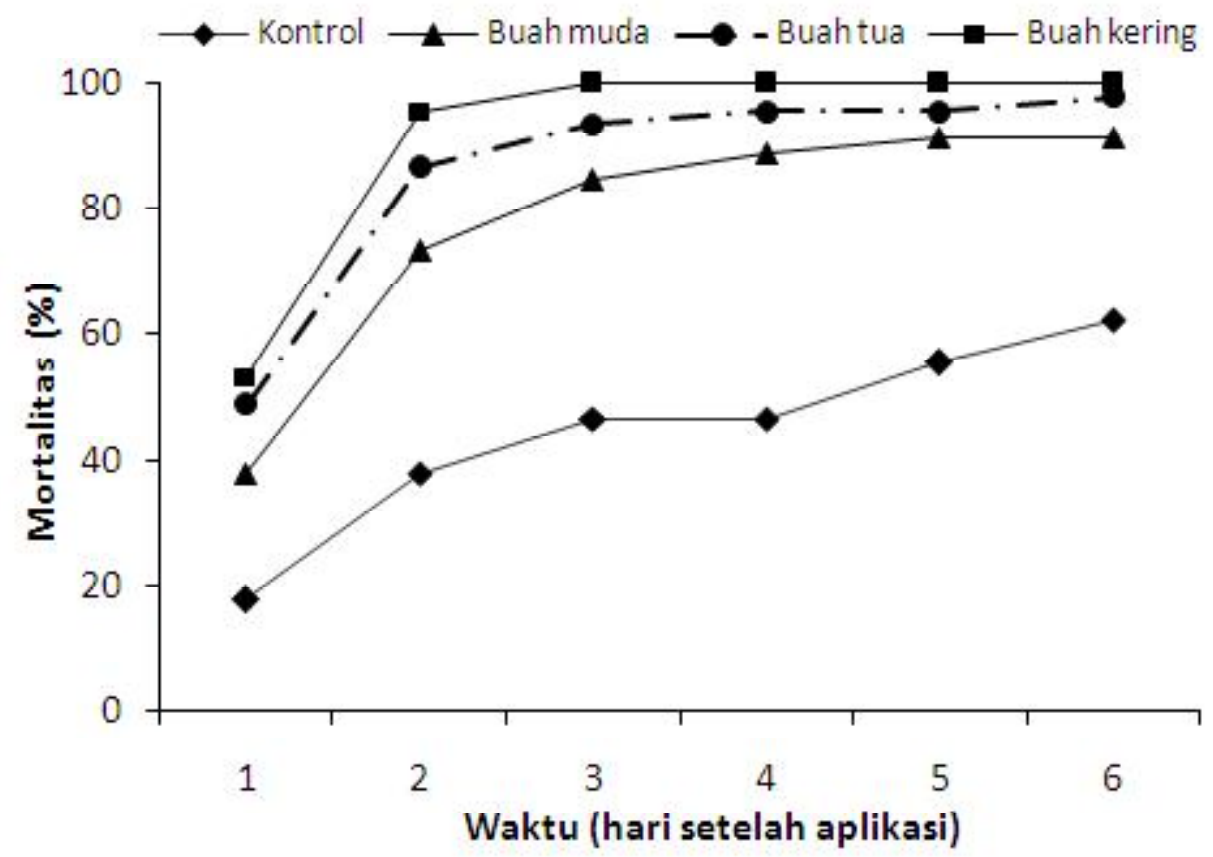

Gambar 1. Pengaruh jenis ekstrak buah Brucea javanica terhadap mortalitas larva Heortia vitessoides 
buah kering secara signifikan lebih tinggi dari dua jenis ekstrak lainnya hanya pada hari ke-3 setelah aplikasi. Selain hal tersebut, adanya fakta bahwa dalam waktu 5 hari baik ekstrak buah Brucea muda, tua maupun kering telah menimbulkan mortalitas lebih dari $90 \%$ serangga uji, maka sesungguhnya untuk penerapan di lapangan dapat digunakan ekstrak dari jenis buah yang manapun serta tanpa diperlukan upaya khusus seperti pengeringan.

\section{Penghambatan Makan Larva $\boldsymbol{H}$. vitessoides Akibat} Aplikasi Ekstrak Buah Brucea. Perlakuan ekstrak buah Brucea terhadap aktivitas makan larva $H$. vitessoides pada metode tanpa pilihan menunjukkan pengaruh yang berbeda dibandingkan kontrol. Perbedaan tersebut terlihat dalam hal luas daun maupun bobot daun yang dimakan larva (Tabel 2). Pada hari pertama pemberian ekstrak, aktivitas makan seluruh serangga uji masih terlihat normal. Selanjutnya daya makan menurun pada hari kedua, yang tercermin pada luas maupun bobot daun yang dikonsumsi. Hal ini diduga seiring dengan proses peracunan yang sedang dialami larva. Selain itu juga teramati bahwa tidak ada perbedaan pengaruh antara perlakuan ekstrak buah Brucea muda, tua, maupun buah yang dikeringkan (Tabel 2).

Selanjutnya perlakuan ekstrak buah Brucea terhadap aktivitas makan larva $H$. vitessoides pada metode pilihan menunjukkan pengaruh yang nyata dibandingkan kontrol pada peubah luas daun yang dimakan hanya pada pengamatan hari pertama setelah aplikasi. Proses peracunan yang dialami oleh serangga uji diduga telah menyebabkan menurunnya perilaku makan tersebut, yang tercermin dengan semakin berkurangnya luas daun yang dikonsumsi larva pada hari kedua serta tidak menunjukkan adanya perbedaan dengan kontrol (Tabel 3). Hal yang serupa juga tampak pada pengamatan terhadap peubah bobot daun yang dikonsumsinya (Tabel 4).
Berdasarkan pengurangan luas dan bobot daun yang dikonsumsi serangga uji diketahui bahwa daya penghambatan makan ekstrak buah Brucea terhadap larva $H$. vitessoides tampak cukup tinggi pada 2 hari setelah aplikasi yang diakibatkan oleh ekstrak buah tua dan buah kering pada pengujian tanpa pilihan yaitu pada kisaran 68-70\% (berdasarkan bobot daun) dan 74-77\% (berdasarkan luas daun) (Tabel 5). Tingkat penghambatan ini lebih tinggi dibandingkan pada metode dengan pilihan (Tabel 6). Keberadaan larva dalam bejana yang di dalamnya terdapat pakan selain daun yang diberi perlakuan mendorong serangga tersebut masih cukup banyak melakukan aktivitas makan. Pada percobaan lain, misalnya Zeng et al. (2006) yang menggunakan ekstrak kloroform buah Brucea pada konsentrasi $10 \mathrm{mg} /$ $\mathrm{ml}$ terlihat adanya daya antifeedan yang kuat $(95,5 \%)$ terhadap ulat Pieris rapae. Sedangkan ekstrak metanol buah Brucea pada konsentrasi 0,06-0,25\% menghambat aktivitas makan larva $C$. pavonana sebesar 91,8-97,2\% (Syahputra, 2008).

\section{Penghambatan Pertumbuhan $\boldsymbol{H}$. vitessoides Akibat Aplikasi Ekstrak Buah Brucea. Pemberian} perlakuan ekstrak buah Brucea javanica terlihat nyata menghambat pertumbuhan dan perkembangan larva $H$. vitessoides. Penghambatan tersebut tampak sejak proses ganti kulit larva dari instar-3 ke instar-4, proses pupasi, hingga munculnya serangga dewasa (Tabel 7). Selain hal itu, perlakuan tersebut juga berpengaruh memperpendek total rentang stadia pertumbuhan serangga uji sejak larva instar-3 hingga imago (Tabel 8).

Mortalitas yang dialami oleh sebagian besar serangga uji hingga tinggal menyisakan sebanyak 4-17\% larva yang dapat meningkat ke instar-4, hanya $2-8 \%$ yang menjadi pupa, dan bahkan tidak satu pun serangga uji yang muncul menjadi serangga dewasa. Diantara

Tabel 2. Pengaruh ekstrak buah Brucea javanica terhadap luas dan bobot daun yang dimakan larva $H$. vitessoides pada metode tanpa pilihan

\begin{tabular}{lcccc}
\hline \multirow{2}{*}{ Perlakuan } & \multicolumn{2}{c}{$\begin{array}{c}\text { Luas daun yang dimakan larva pada: } \\
\left(\mathrm{mm}^{2}\right)\end{array}$} & \multicolumn{2}{c}{ Bobot daun yang dimakan larva pada: } \\
& $1 \mathrm{mg})$ \\
\cline { 2 - 5 } & $1 \mathrm{hsa}$ & $2 \mathrm{hsa}$ & $1 \mathrm{hsa}$ & $2 \mathrm{hsa}$ \\
\hline Kontrol & $471,2 \mathrm{a}$ & $189,3 \mathrm{a}$ & $0,5110 \mathrm{a}$ & $0,0268 \mathrm{a}$ \\
Buah muda & $424,7 \mathrm{ab}$ & $97,0 \mathrm{ab}$ & $0,5085 \mathrm{ab}$ & $0,0245 \mathrm{ab}$ \\
Buah tua & $414,4 \mathrm{ab}$ & $16,4 \mathrm{~b}$ & $0,5016 \mathrm{ab}$ & $0,0228 \mathrm{ab}$ \\
Buah kering & $360,9 \mathrm{~b}$ & $8,6 \mathrm{~b}$ & $0,5024 \mathrm{~b}$ & $0,0206 \mathrm{~b}$ \\
\hline F hitung ${ }^{1)}$ & $5,27 * *$ & $8,23 * *$ & $3,986 * *$ & $5,786 * *$ \\
\hline BNT 0,05 & 79,697 & 6,986 & 0,007 & 0,004 \\
\hline
\end{tabular}


Tabel 3. Pengaruh ekstrak buah Brucea javanica terhadap luas daun yang dimakan larva $H$. vitessoides pada metode pilihan

\begin{tabular}{ccccccc}
\hline \multirow{2}{*}{$\begin{array}{c}\text { Perlakuan yang } \\
\text { dibandingkan }\end{array}$} & \multicolumn{5}{c}{ Rerata luas daun yang dimakan $\left(\mathrm{mm}^{2}\right)$} \\
\cline { 2 - 7 } & Ekstrak & Kontrol & thitung & Ekstrak & Kontrol & thitung \\
\cline { 2 - 7 } & 450,78 & 501,63 & $2,12^{* *}$ & 187,27 & 189,67 & $0,03^{\text {tn }}$ \\
Buah muda vs kontrol & 393,43 & 469,98 & $2,08^{* *}$ & 31,06 & 51,66 & $0,51^{\text {tn }}$ \\
Buah tua vs kontrol & 377,43 & 459,03 & $2,46^{* *}$ & 97,28 & 100,93 & $0,05^{\text {tn }}$ \\
Buah kering vs kontrol & 377 &
\end{tabular}

hsa $=$ hari setelah aplikasi, ${ }^{*} *$ = berbeda pada taraf nyata $1 \%$ pada Uji $\mathrm{t}, \mathrm{tn}=$ tidak berbeda pada taraf nyata $5 \%$ pada Uji t.

Tabel 4. Pengaruh ekstrak buah Brucea javanica terhadap bobot daun yang dimakan larva $H$. vitessoides pada metode pilihan

\begin{tabular}{ccccccc}
\hline \multirow{2}{*}{$\begin{array}{c}\text { Perlakuan yang } \\
\text { dibandingkan }\end{array}$} & \multicolumn{5}{c}{ Rerata luas daun yang dimakan $\left(\mathrm{mm}^{2}\right)$} \\
\cline { 2 - 7 } & Ekstrak & Kontrol & t hitung & Ekstrak & Kontrol & thitung \\
\cline { 2 - 7 } & 0,023 & 0,030 & $2,22^{* *}$ & 0,015 & 0,015 & $0,084^{\text {tn }}$ \\
Buah muda vs Kontrol & 0,026 & 0,036 & $2,99^{* *}$ & 0,005 & 0,006 & $0,304^{\text {th }}$ \\
Buah tua vs Kontrol & 0,025 & 0,028 & $0,84^{\text {tn }}$ & 0,006 & 0,008 & $0,40^{\text {nn }}$ \\
Buah kering vs Kontrol & 0,25 &
\end{tabular}

hsa $=$ hari setelah aplikasi, ${ }^{*} *$ = berbeda pada taraf nyata $1 \%$ pada Uji $\mathrm{t}, \mathrm{tn}=$ tidak berbeda pada taraf nyata $5 \%$ pada Uji t.

Tabel 5. Penghambatan makan larva $H$. vitessoides oleh ekstrak buah Brucea javanica berdasarkan luas dan bobot daun yang dimakan larva pada metode tanpa pilihan

\begin{tabular}{lrrrr}
\hline & \multicolumn{4}{c}{ Penghambatan makan (\%) } \\
\cline { 2 - 5 } Perlakuan ekstrak & \multicolumn{3}{c}{ luas daun } & \multicolumn{3}{c}{ bobot daun } \\
\cline { 2 - 5 } & $1 \mathrm{hsa}$ & 2 hsa & 13,86 & $-4,72$ \\
& 9,31 & 38,14 & 22,63 & 68,33 \\
Buah muda & 23,36 & 77,17 & 8,07 & 70,02 \\
Buah tua & 11,76 & 74,31 & & \\
Buah kering & & &
\end{tabular}

Tabel 6. Penghambatan makan larva $H$. vitessoides oleh ekstrak buah Brucea javanica berdasarkan luas dan bobot daun yang dimakan larva pada metode pilihan

\begin{tabular}{lrcrc}
\hline & \multicolumn{4}{c}{ Penghambatan makan (\%) } \\
\cline { 2 - 5 } Perlakuan ekstrak & \multicolumn{2}{c}{ luas daun } & \multicolumn{3}{c}{ bobot daun } \\
\cline { 2 - 5 } & 1 hsa & 2 hsa & 1 hsa & 2 hsa \\
\cline { 2 - 5 } & 5,65 & 0,80 & 13,98 & $-0,02$ \\
Buah muda & 11,91 & 2,63 & 16,36 & 2,87 \\
Buah tua & 11,21 & 0,36 & 6,64 & 4,65 \\
Buah kering & & &
\end{tabular}


Tabel 7. Pengaruh ekstrak buah Brucea javanica terhadap kemunculan larva instar-4, pembentukan pupa serta imago $H$. vitessoides

\begin{tabular}{lccc}
\hline Perlakuan ekstrak & $\begin{array}{c}\text { Kemunculan } \\
\text { instar-4 }(\%)\end{array}$ & $\begin{array}{c}\text { Pembentukan } \\
\text { pupa (\%) }\end{array}$ & $\begin{array}{c}\text { Kemunculan } \\
\text { imago (\%) }\end{array}$ \\
\hline Kontrol & $53,33 \mathrm{a}$ & $35,55 \mathrm{a}$ & $35,55 \mathrm{a}$ \\
Buah muda & $17,78 \mathrm{~b}$ & $8,89 \mathrm{~b}$ & $0,00 \mathrm{~b}$ \\
Buah tua & $4,44 \mathrm{c}$ & $2,22 \mathrm{c}$ & $0,00 \mathrm{~b}$ \\
Buah kering & $0,00 \mathrm{c}$ & $0,00 \mathrm{c}$ & $0,00 \mathrm{~b}$ \\
\hline F-hitung ${ }^{1)}$ & $25,77^{* *}$ & $38,11^{* *}$ & $841,39 * *$ \\
\hline${ }^{1)}=$ data ditransformasi dengan $\sqrt{(x+0,5)}, * *$ berbeda nyata pada taraf $1 \%$. Nilai-nilai dalam kolom yang diikuti \\
huruf yang sama menunjukkan, tidak berbeda menurut uji BNT (p>0,05).
\end{tabular}

Tabel 8. Pengaruh ekstrak buah Brucea javanica terhadap lama stadia larva instar-3, larva instar-4, pupa dan imago H. vitessoides

\begin{tabular}{lccrr}
\hline \multirow{2}{*}{ Perlakuan ekstrak } & \multicolumn{4}{c}{ Lama stadia (jam) } \\
\cline { 2 - 5 } & Instar-3 & Instar-4 & Pupa & Imago \\
\hline Kontrol & 33,07 & $67,95 \mathrm{a}$ & $108,98 \mathrm{a}$ & $322,98 \mathrm{a}$ \\
Buah muda & 29,87 & $73,61 \mathrm{a}$ & $117,33 \mathrm{a}$ & $0,00 \mathrm{~b}$ \\
Buah tua & 32,53 & $65,33 \mathrm{a}$ & $16,00 \mathrm{~b}$ & $0,00 \mathrm{~b}$ \\
Buah kering & 29,20 & $0,00 \mathrm{~b}$ & $0,00 \mathrm{~b}$ & $0,00 \mathrm{~b}$ \\
\hline F-hitung $^{1)}$ & $0,51^{\text {tn }}$ & $5,07^{*}$ & $16,38^{* *}$ & $5224,1^{* *}$ \\
\hline
\end{tabular}

1) = data ditransformasi dengan $\sqrt{(x+0,5)}$, tn $=$ tidak berbeda pada taraf $5 \%, *=$ berbeda pada taraf $5 \%$, ** $=$ berbeda pada taraf $1 \%$, nilai dalam kolom yang diikuti dengan huruf yang sama menunjukkan tidak berbeda pada uji BNT ( $p>0,05)$.

ketiga jenis ekstrak yang diujikan, tampak ekstrak buah tua dan buah kering memiliki daya hambat yang nyata lebih tinggi dibandingkan ekstrak buah muda terhadap pertumbuhan larva menjadi instar-4 serta pembentukan pupa. Namun demikian ketiga perlakuan ekstrak tersebut seluruhnya tidak memberi peluang serangga uji untuk muncul menjadi imago.

\section{SIMPULAN}

Ekstrak buah Brucea javanica baik yang berasal dari buah muda, tua, maupun buah kering pada konsentrasi $50 \mathrm{~g} / 1$ nyata efektif mematikan larva pemakan daun gaharu Heortia vitessoides dengan kisaran mortalitas 73,3-95,5\% sejak dua hari setelah diaplikasikan. Bahkan ekstrak buah kering telah mematikan seluruh serangga uji pada hari ke-3 setelah aplikasi. Selain hal itu juga diketahui bahwa pada 2 hari setelah aplikasi, ekstrak buah tua dan buah kering memiliki pengaruh antifeedant terhadap larva $H$. vitessoides sebesar $68-70 \%$ berdasarkan bobot daun dan $74-77 \%$ berdasarkan luas daun yang dimakan. Lebih lanjut akibat perlakuan ekstrak buah Brucea tersebut hanya kurang dari $10 \%$ larva uji yang dapat menjadi pupa dan tidak satu pun yang mencapai tahap imago.

\section{SANWACANA}

Penulis menyampaikan penghargaan dan terima kasih kepada Saudari Tria Agustina dan Riska Febriani yang telah memberikan bantuan teknis dalam penelitian ini.

\section{DAFTAR PUSTAKA}

Evans DH \& Crossley S. 2010. Heortia vitessoides (Moore, 1885). http://lepidoptera butterflyhouse. com.au/odon/vitessoides.html. Diakses 22 Februari 2011. 
Feng X, Jiang H, Zhang Y, He W \& Zhang L. 2012. Insecticidal activities of ethanol extracts from thirty Chinese medicinal plants against Spodoptera exigua (Lepidoptera: Noctuidae). Journal of Medicinal Plants Research 6(7): 1263-1267. http://www.academicjournals.org/ JMPR. Diakses 2 Maret 2012.

Globinmed. 2010. Brucea javanica (L.) Merr. Global Information Hub on Integrated Medicine. http:// w w w . g l o b i n m e d. c o m / index.php?option=com\&content\&view. Diakses 2 Juni 2011.

Gurung D, Dutta N \& Sharma PC. 2002. On the Insect Pests of Aquilaria agallocha (Roxb.). Rain Forest Research Institute Report. http:// rfri.icfre.gov.in/rpap13.htm. Diakses 22 Februari 2011.

Hariri AM \& Indriyati. 2011. Karakterisasi Hama Pemakan Daun Mahkota Dewa (Phaleria macrocarpa [Scheff.] Boerl.). Ginting C \& Hendri J. Eds. Prosiding Seminar Hasil-hasil Penelitian dan Pengabdian Kepada Masyarakat. Lembaga Penelitian Universitas Lampung. Hlm. I-64 - I-70.

Hassanali A \& Bentley MD. 1987. Comparison of the insect antifeedant activities of some limonoids. P. 683-689 In Schmutterer $\mathrm{H}$ \& Ascher KRS (Eds.). Natural Pesticides from the Neem Tree and Other Tropical Plant. Third International Neem Conference. Kenya.

Irianto RSB, Santoso E, Turjaman M \& Sitepu IR. 2010. Hama pada Pohon Penghasil Gaharu dan Teknik Pengendaliannya. Info Hutan 7 (2): 225-228.

Jayaweera DMA. 1982. Medicinal Plants, Part V Rutaceae-Zygophyllaceae. The National Science Council of Sri Lanka. Colombo.

Kalita J, Bhattacharyya PR \& Nath SC. 2002. Heortia vitessoides Moore: A Serious Pest of Agarwod Plant (Aquilaria malaccensis Lamk). Geobios 29: 13-16.

Lina EC, Arneti, Prijono D \& Dadang. 2010. Potensi insektisida melur (Brucea javanica L. Merr.) dalam mengendalikan hama kubis Crocidolomia pavonana (F.) (Lepidoptera: Crambidae) dan Plutella xylostella (L.) (Lepidoptera: Yponomeutidae). J. Natur Indonesia 12(2): 109-116.
Liu KCS, Yang SL, Roberts MF \& Phillipson JD. 1990. Canthin-6-one alkaloids from cell suspension cultures of Brucea javanica. Phytochemistry 29 (1): 141-143.

Luo YP, Lu YQ \& Fu YG. 2009. Preliminary Studies on Antifeeding Actions of Brucea javanica Extracts against Spodoptera litura Fabricius. J. Modern Agrochemicals 2009-02. Online abstract. http:/ /en.cnki.com.cn/Article_en/. Diakses 5 Mei 2011.

Nakao R, Mizukami C, Kawamura Y, Subeki, Bawm S, Yamasaki M, Maede Y, Matsuura H, Nabeta K, Nonaka N, Oku Y \& Katakura K. 2009. Evaluation of efficacy of bruceine A, a natural quassinoid compound extracted from a medicinal plant, Brucea javanica for canine babesiosis. $J$. Vet. Med. Sci. 71(1): 33-41. http:// www.ncbi.nlm.nih.gov/pubmed/19194074. Diakses 2 Juni 2011.

Okano M, Fukamiya N, Tagahara K, Tokuda H, Iwashima A, Nishino H \& Lee KH. 1995. Inhibitory effects of quassinoids on Epstein-Barr virus activation. Cancer Letters 94 (2): 139-146.

Paczkowska G. 1996. Brucea javanica (L.) Merr. Department of Environment and Conservation, Western Aurtralian Herbarium. http:// florabase.dec.wa.gov.au./browser/profile/4509. Diakses 2 Juni 2011.

Prijono D. 2005. Pengembangan dan Pemanfaatan Insektisida Botani (Bahan Pelatihan). Departemen Proteksi Tanaman Fakultas Pertanian Institut Pertanian Bogor. Bogor.

Qin LY, Guo CL, Zeng T, Miao JH, Chen HS \& Li LF. 2007. Effects of 19 plant extracts and their activecomponents against Nilaparvata lugens Stal. oviposition deterrent activity. Guangxi Agricultural Sciences 2007-06. On-line Abstract. http://en.cnki.com.cn/Article_en/. Diakses 2 Juni 2011.

Roberts MF. 1994. Brucea spp.: In vitro culture and production of canthinone alkaloids and other secondary metabolites. In Bajaj YPS. (Ed.) Medicinal and Aromatic Plants. SpringerVerlag, Berlin, Heidelberg. p. 21-45.

Santoso E, Irianto RSB, Sitepu IR \& Turjaman M. 2011. Penanggulangan Hama dan Penyakit Tanaman Penghasil Gaharu. Presentasi pada Badan Litbang Kehutanan. Jakarta, 25 Mei 2011. 
Shang XK, Wei DW, Zhou XH, Zeng T, Zeng XR, \& Wang ZY. 2008. Biological activity of Brucea javanica (L.) Merr. extracts against Myzus persicae (Sulzer). Southwest China J. of Agric. Sci. 21(6): 1591-1594.

Shen GS, Zhang ZK, Wu ZJ, Ouyang MA, Xie LH \& Lin YL. 2008. Antiphytoviral activity of bruceineD from Brucea javanica seeds. J. Pest Management Science 64 (2): 191-196. Online abstract. http://onlinelibrary. wiley.com/doi/ 10.1002/ps.1465/abstract. Diakses 5 Mei 2011.

Siran SA, \& Turjaman M. 2010. Pengembangan Teknologi Produksi Gaharu Berbasis Pemberdayaan Masyarakat Sekitar Hutan. Pusat Penelitian dan Pengembangan Hutan dan Konservasi Alam. Bogor.

Sokal RR \& Rohlf FJ. 1981. Biometry: The Principles and Practices of Statistics in Biological Research. W.H. Freeman \& Company, California.
Syahputra E. 2008. Bioaktivitas sediaan buah Brucea javanica sebagai insektisida nabati untuk serangga hama pertanian. Bull. Littro.19(1): 5767.

Walpole RE. 1995. Pengantar Statistika. Terjemahan oleh B. Sumantri. PT Gramedia Pustaka Utama. Jakarta.

WHO. 1999. WHO Monographs on Selected Medicinal Plants - Volume 1: Fructus Brucea. apps.who.int/ medicinedocs/en/d/Js2200e/8.html. Diakses 2 Juni 2011.

Zeng T, Li LF, Wei DW, Chen HS \& Liu Y. 2006. Effect of Brucea javanica extracts on feeding and growth and development of Pieris rapae larvae. J. Agrochemicals 2006-03. Online abstract. http://en.cnki.com.cn/Article_en/. Diakses 5 Mei 2011. 